\title{
URGENSI PENGENALAN PENDIDIKAN SEKS PADA ANAK DALAM RUMAH TANGGA (TINJAUAN PENDIDIKAN ISLAM)
}

\author{
SYEKHA \\ SMA Negeri 2 Tanjung Selor \\ e-mail : syekhatea@gmail.com
}

\begin{abstract}
ABSTRAK
Tujuan penulis membuat artikel ini adalah untuk memberikan pemahaman kepada masyarakat khususnya orang tua bahwa bimbingan pendidikan seks perlu diberikan kepada anak sejak dini. Dengan memberikan pemahaman dan bimbingan pendidikan seks dalam konteks islam kepada anak diharapkan anak akan tumbuh menjadi generasi muda yang beriman dan bertaqwa serta mampu menjaga kehormatan dan kesucian diri mereka. Penulisan artikel ini menggunakan studi kepustakaan/literatur dengan menghimpun data melalui kajian teks dan berbagai referensi buku yang berkaitan dengan pendidikan islam dan pendidikan seks yang sesuai dengan ajaran islam.Dengan memahami dan memberikan pendidikan seks kepada anak yang sesuai dengan ajaran islam maka anak akan tumbuh menjadi individu yang taat kepada agama nya dan mampu menjaga harga dirinya dihadapan Allah swt dan di hadapan manusia,serta menjadikannya manusia yang sehat akalnya, jasmaninya, serta ruhnya sehingga kehidupan anak akan menjadi mulia kehidupannya.
\end{abstract}

Kata Kunci: pendidikan seks , pada anak ,pandangan islam

\section{PENDAHULUAN}

Manusia sebagai makhluk Tuhan, telah dikaruniai oleh Allah kemampuan dasar yang bersifat rohania dan jasmaniah, agar dengannya manusia mampu mempertahankan hidup serta memajukan kesejahteraannya. Dan sarana yang dibutuhkan untuk pengembangan kehidupan manusia tidak lain adalah pendidikan, karena pendidikan merupakan kunci dari segala bentuk kemajuan hidup umat manusia sepanjang sejarah (Arifin,2000). Pendidikan dalam arti luas bermakna mengubah dan memindahkan nilai-nilai kebudayaan individu dalam masyarakat ( Langgalung,1985 ). Sedangkan menurut Marimba (1994) menuliskan dalam bukunya yang berjudul "filsafat pendidikan islam" mengatakan bahwa pendidikan islam adalah bimbingan jasmani, rohani berdasarkan hukum-hukum agama islam menuju kepada terbentuknya kepribadian utama nenurut ukuran-ukuran islam.

Jelaslah bahwa proses pendidikan merupakai rangkaian usaha membimbing atau mengarahkan potensi manusia yang berupa kemampuan dasar dan kemampuan belajar ,sehingga terjadilah perubahan didalam kehidupan setiap individu sebagai makhluk sosial serta hubungannya dengan alam sekitarnya dimana dia hidup . Proses ini senantiasa berada dalam nilai-nilai islami ,artinya nilai-nilai yang melahirkan norma akhlak al karimah.

Lingkungan pertama dimana anak mengenyam pendidikan adalah lingkungan keluarga dan pelaku dari pada pendidikan adalah orang tua. Hal ini disebabkan bahwa kebiasaan yang dimiliki anak-anak sebagian besar terbentuk oleh pendidikan keluarga. Untuk itu orang tua harus memberikan pendidikan yang baik pada anaknya terutama masalah pembetukan jiwa keagamaan pada anak-anak, agar anak diharapkan mampu tumbuh menjadi generasi muda yang beriman dan bertakwa serta mampu menjaga kehormatan dan kesucian diri mereka.

Munculnya isu pendidikan seks menjadikan polemik tersendiri dalam berbagai bidang dan tentunya memunculkan realitas dan fenomena yang cukup penting di masyarakat. Beberapa kalangan menilai bahwa pendidikan seks adalah sesuatu yang tabu dan tidak perlu untuk diajarkan kepada anakanak, karena ini adalah sesuatu yang instingtif dan cukup sensitif jika dibicarakan. Beberapa pihak lain berpendapat bahwa pendidikan seks adalah pengetahuan yang perlu untuk diketahui oleh anak-anak sebagai modal untuk menghadapi usia remaja dan usia pubertas dan untuk kelanjutan kehidupannya dalam berumah tangga. 
Dalam perkembangan kajian keislaman, baru-baru ini dikenal dengan altarbiyyah al-jinsiyyah (pendidikan seksual). Di Indonesia sudah cukup banyak kajian yang membahas masalah pendidikan seks dalam perspektif Islam. Beberapa kajian menyimpulkan bahwasanya pendidikan seks (al-tarbiyyah al-jinsiyyah) dalam Islam merupakan bagian dari pendidikan akhlaq, karena selain membahas masalah seksualitas, pendidikan seks juga membahas etika berpakaian, tingkah laku, pergaulan, kebersihan, dan ibadah. 2 Pendapat lain menjelaskan bahwa pendidikan seks merupakan pendidikan moral yang terkait dengan masalah keimanan dan keislaman secara harmonis (Indrawati,2005)

Salah satu cara menangani perilaku seks bebas pada remaja adalah dengan cara mengajarkan pendidikan seks menurut Islam. Karena konsep pendidikan seks dalam Islam bukanlah mengajarkan cara melakukan hubungan seksual yang aman dan agar tidak terjadi kehamilan, namun mengajarkan bagaimana cara menjauhi perzinahan dan perilaku seksual yang menyimpang, maka pendidikan agama, biologi, dan pendidikan jasmani dapat diintegrasikan untuk memberikan pemahaman kepada siswa mengenai pendidikan seks. Artinya pendidikan seks dalam Islam berorientasi kepada moral dan kepribadian, bukan berorientasi pada kesehatan dan akademis saja. Sebagaimana dalam Psikologi Islam tujuan pendidikan adalah untuk membentuk kualitas nafs ( Zulpiadi dalam Rusydi ,2012)

Hal inilah yang membedakan antara pendidikan seks di dalam konsep Islam dan konsep Barat. Di Barat, munculnya pendidikan seks biasanya dilatarbelakangi oleh kasus dan masalah seksual yang terjadi dan menjadi suatu permasalah yang cukup merugikan (Sehmied dan Reidl dalam Rusdy ,2012). Munculnya pendidikan seks dilatarbelakangi oleh perilaku remaja yang melakukan hubungan seks yang tidak aman dan kasus-kasus penyakit seksual lainnya. Seiring dengan menipisnya pendidikan keislaman di Indonesia, seiring pula meningkatnya angka seks bebas. Hal ini wajar saja karena norma mengenai seksualitas yang diajarkan oleh Islam semakin lama-semakin menipis sehingga kesadaran masyarakat untuk melakukan kontrol diri menjadi berkurang. Padahal Islam sangat banyak sekali memberikan ajaran-ajaran moral mengenai seksualitas.

Pendidikan seks dapat diberikan melalui lembaga pendidikan yang pertama bagi anak sebelum dia mengenal sekolah. keluarga merupakan mikrokosmos tempat manusia baru diciptakan dan merupakan sumber yang banyak memberikan dasar-dasar ajaran bagi seseorang dan merupakan faktor yang penting dalam pembinaan mental, sebelum seorang anak berinteraksi dengan lingkungan masyarakat terlebih dahulu menerima pengalaman-pengalaman dari keluarga di rumah, terutama ibu dan kemudian ayah dan kerabat-kerabatnya. Agar interaksi dengan anggota masyarakat berjalan dengan mulus dan tidak banyak mengalami rintangan maka diperlukan adanya landasan moral yang kuat untuk mendasari pembinaan keluarga tersebut (Ramayulis ,1998). Rumah tangga sebagai salah satu lembaga pendidikan, maka eksistensi orang tua dalm rumah tangga harus benar-benar bertanggung jawab atas pelaksanaan pendidikan dalam lingkungan keluarganya. Islam telah memberikan pedoman yang bersifat praktis, meskipun manusia diberi keleluasan untuk menyalurkan hasrat seksualnya, namun bukan berarti melaksanakan kebebasan seksual, sehingga didalam Islam terdapat aturan-aturan yang berkenaan dengan masalah seksual ini. Banyak petunjuk yang diberikan Al-qur'an, dan banyak pula contoh-contoh perbuatan yang dilakukan Rasulullah Saw sebagai dasar pendidikan seksual, salah satu contoh ajaran Islam yang berkenaan dengan masalah seksual, yaitu larangan hidup membujang, menjaga pandangan mata terhadap lawan jenis yang bukan mahramnya, adab bersetubuh dan lain sebagainya.

Berdasarkan fenomena yang ada ,maka orang tua harus memberikan pendidikan yang bersifat menjaga kehormatan dan kesucian diri anak yang berpedoman pada ajaran islam. Salah satu cara mengatasi fenomena ini yaitu dengan cara memberikan pendidikan penanaman iman ,pengajaran akhlak yang mulia salah satunya dengan cara memberikan pengenalan pendidikan seks yang tepat pada anak usia dini. Orang tua juga perlu menerapkan pembiasaan-pembiasaan adab-adab islami secara sistematis yang akan membentuk dalam diri seseorang ,yaitu kehidupan yang cenderung benar dan sesuai dengan nilai-nilai ajaran islam.

Salah satu metode dan pendekatan yang diajarkan dalam islam adalah dimana islam telah meletakkan ajaran-ajaran yang dapat dianggap sebagai bagian dari pendidikan yang dapat diberikan secara bertahap, misalnya ketika seorang anak masih berumur $7-10$ tahun, kita diajarkan memisahkan kamar tidur anak laki-laki dan anak perempuan sebagaimana sabda 
Rasulullah Saw : “perintahkanlah anak-anak kalian untuk melaksanakan sholat pada umur 7 tahun dan pukullah mereka jika mereka tidak melaksanakan sholat pada umur sepuluh tahun dan pisahkan tempat tidur mereka.(H.R.Abu Daud)”.

Pendidikan seksual didalam islam,merupakan pendidikan aqidah, akhlak, dan ibadah. Pendidikan seksual tidak bisa lepas dari ketiga unsur diatas. Keterlepasan pendidikan seksual dengan ketiga unsur ini akan menyebabkan ketidak jelasan arah dari pendidikan seksual tersebut. Bahkan akan dapat menimbulkan kesesatan dan penyimpangan dari tujuan asal, sebab pendidikan seksual yang lepas dari aqidah akhlak dan ibadah hanyalah akan berdasarkan hawa nafsu semata ( Syafruddin,1995).

Pendidikan seksual bertujuan memberikan pelajaran dan pengertian kepada anak baik laki-laki maupun perempuan sejak ia mulai mmemasuki usia baliq, serta berterus terang kepadanya kepadanya tentang masalah-masalah yang berhubungan dengan seks, naluri dan perkawinan ( Ath-Thawil,2000).

Pendidikan seks anak usia dini bukanlah pendidikan yang mengajarkan anak bagaimana cara berhubungan seksual, tetapi pendidikan seks pada anak usia dini merupakan pendikan seks yang berkaitan dengan memberikan penerangan yang bertujuan untuk membimbing serta mengasuh setiap laki-laki maupun perempuan sejak anak-anak sampai dewasa didalam perihal pergaulan antara kelamin pada umumnya dan kehidupan seks pada khususnya.

Dari latar belakang yang ada maka penulis membuat artikel tentang perlunya pendidikan seks islam pada anak usia dini dalam keluarga untuk memberikan pemahaman kepada orang tua dan anak bagaimanakah pendidikan seks berdasarkan islam sehingga bisa dipraktekkan dalam kehidupan sehari-hari sehingga dapat membawa anak kedalam kehidupan yang baik, aman, sehat, sejahtera dan bahagia dunia akhirat.

\section{METODE PENELITIAN}

Metode yang digunakan dalam penyusunan artikel ini,penulis menggunakan metode pendekatan paedagogik ,yaitu pendekatan yang berusaha menggunakan teori-teori kependidikan yang berkaitan dengan pokok permasalahan yang dibahas, sehingga mempermudah mengetahui substansi dari pembahasan dengan jelas. Dan pendekatan psikologis,yaitu suatu pendekatan yang digunakan berdasarkan teori-teori kemasyarakatan.

Dalam hal memperoleh data yang berhubungan dengan obyek yang dibahas dalam artikel ini penulis menggunakan metode "Library Research" yaitu pengumpulan data melalui pendekatan kepustakaan serta dokumentasi-dokumentasi yang berkaitan dengan Obyek pembahasan yang relevan. Pengelolahan data penulis menggunakan metode deskriptifkualitatif, metode ini sebagaimana di jelaskan oleh Mattew B Miles dan Michael A Huberman (dalam Pedoman Penulisan Skripsi Dan Makalah Sekolah Tinggi agama Islam Negeri ,2003:68). Adalah singkatnya, hal-hal yang terdapat dalam analisa kualitatif ? pertama, data yang muncul berwujud kata-kata dan bukan rangkaian angka....

a. Metode induktif yaitu suatu metode analisis penulisan yang dimulai dari masalah atau fakta-fakta yang bersifat khusus kemudian ditarik kedalam hal-hal yang bersifat umum.

b. Metode deduktif yaitu suatu metode analisis penulisan yang dimulai hal-hal yang bersifat umum kemudian ditarik kedalam hal-hal yang bersifat khusus.

c. Metode komparatif, yaitu suatu metode analisis penulisan yang bersifat membandingkan antara pendapat yang satu dengan yang lainnya kemudian ditarik dalam suatu kesimpulan umum.

\section{HASIL DAN PEMBAHASAN}

Berdasarkan hasil pencarian studi literatur maka penulis membuat artikel yang berjudul Urgensi Pengenalan Pendidikan Seks Pada Anak Dalam Rumah Tangga berdasarkan tinjauan pendidikan islam, dalam artikel ini penulis akan membahas seputar tentang pendidikan seks dalam islam, tujuan, fungsi serta bentuk pendidikan seks yang diberikan kepada anak 
berdasarkan ajaran islam dan manfaat daripada pemberian pendidikan seks pada anak dalam konteks islam.

Dalam penulisan artikel ini penulis menggunakan 21 referensi buku yang berkaitan dengan pendidikan secara umum dan pendidikan seks dalam islam secara khusus.

Tabel 1. Analisis Pengenalan Pendidikan Seks Pada Anak dalam Rumah Tangga Dalam Tinjauan Islam.

\begin{tabular}{|c|c|c|}
\hline No & Nama Penulis & Judul Buku \\
\hline 1 & H.M.Arifin ,1994 & Pengantar Filsafat Pendidikan Islam \\
\hline 2 & Hasan lamggalung ,1985 & Manusia Dan Pendidikan \\
\hline 3 & D.Ahmad Marimba ,1994 & Filsafat Pendidikan Islam \\
\hline 4 & Dewi Indrawati, 2005 & Pendidikan Seks dalam Perspektif Ali Akbar \\
\hline 5 & Ahmad Rusydi, 2012 & $\begin{array}{l}\text { Pendidikan Seks Dalam Perspektif Psikologi } \\
\text { Islam }\end{array}$ \\
\hline 6 & Ramayulis, 1998 & Ilmu Pendidikan Islam \\
\hline 7 & Imam Muslim, 1955 & Shahih Muslim \\
\hline 8 & Ayip Syafruddin, 1992 & Islam Dan Pendidikan Seks \\
\hline 10 & Usman Ath- Thawil, 2000 & Ajaran Islam Tentang Fenomena Seksual \\
\hline 11 & B Miles dan Michael A Huberman, 1995 & $\begin{array}{l}\text { Pedoman Penulisan Skripsi \& Makalah Sekolah } \\
\text { Tinggi Agama Negeri }\end{array}$ \\
\hline 12 & $\begin{array}{l}\text { Departemen Pendidikan dan Kebudayaan, } \\
1995\end{array}$ & Kamus Besar Bahasa Indonesia \\
\hline 13 & Ahmad Warson Munawir, 1997 & Kamus Besar Arab Indonesia Al- Munawir \\
\hline 14 & Muhammad Rasyid Ridha, 1935 & Al -Tarbiyah Wa Ta'lim Al -Islam \\
\hline 15 & Zakiah Drajat, 1996 & Ilmu Pendidikan \\
\hline 16 & Akmad Azhar Abu Miqdad, 1997 & $\begin{array}{l}\text { Pendidikan Seks terhadap Remaja Menurut } \\
\text { Hukum Islam }\end{array}$ \\
\hline 17 & Mahfud Shahli, 1994 & Etika Seksual \\
\hline 18 & Syaiful Yusuf, 2003 & Islam dan Pendidikan Seks \\
\hline 19 & Ali Akbar, 1983 & Seksualitas Ditinjau dari Hukum Islam \\
\hline 20 & Abdullah Nashih Ulwan, 1993 & Pedoman Pendidikan Anak Dalam Islam \\
\hline 21 & Sehultz Dan Sehultz, 2005 & Theories of personality, Eight Edition \\
\hline
\end{tabular}

Dalam Kamus Besar Bahasa Indonesia, (1995) kata Urgensi dijelaskan dalam Kamus Besar Bahasa Indonesia memiliki makna sebagai keharusan yang mendesak; hal yang sangat penting.

\section{Pendidikakan Islam}

Kata "Pendidikan" dalam bahasa Arab adalah "Tarbiyah" kata kerja Rabba. kata Pengajaran " dalam bahasa Arab adalah Ta'lim kata kerja allama” jadi kata pendidikan dan pengajaran dalam bahasa Arab "Tarbiyah Wa Ta'lim" sedangkan pendidikan islam dalam bahasa Arab “ Tarbiyah Islamiah” (Munawir,1997)

Pendidikan islam diartikan sebagai usaha mengubah tingka laku individu dalam kehidupan pribadinya atau kehidupan kemasyarakatan dan kehidupan alam sekitarnya melalui proses pendidikan (Arifin, 1994)

Muhammad Rasyid Ridha dalam bukunya yang berjudul “ al Tarbiyah wa ta'lim alislami" menyebutkan bahwa Pendidikan adalah bimbingan daya manusia baik jasmaniyah, akliah, maupun rohaniayah dengan apa yang dapat menjadikan tumbuh dan berkembang serta bergerak sehingga sampai kepada kesempurnaan diri sendiri.

Pendidkan Islam adalah pendidikan yang sadar dan bertujuan untuk merumuskan tujuan umum dan atau tujuan akhir pendidikan Islam, yaitu mengembangkan pemikiran manusia dan mengatur tingkah laku serta perasaan berdasarkan ajaran Islam. Dasar dari tujuan pendidikan islam sebagaimana terdapat dalam surah Al-Imran ayat 112 telah ditegaskan sebagai berikut:

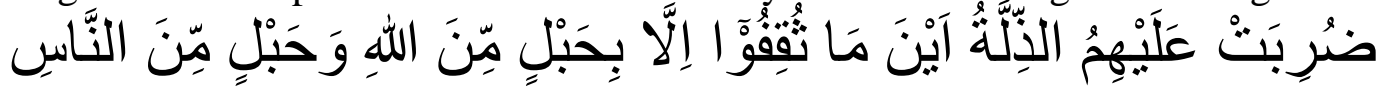

Terjemahannya : 
"Mereka diliputi kehinaan di mana saja mereka berada, kecuali jika mereka (berpegang) pada tali (agama) Allah dan tali (perjanjian) dengan manusia”.

Berdasarkan ayat tersebut, maka secara implisit menyangkut tujuan dari kegiatan pendidikan Islam bagi seseorang perlu diupayakan semaksimal mungkin keberhasilannya, serta sangat urgen untuk diimplementasikan bagi umat manusia sejak dini atau semenjak dari masa kecil dalam rangka menghindarkan diri dari kehinaan dalam hidupnya.

\section{Tujuan Pendidikan Islam}

Tujuan Pendidikan Islam yang paling utama adalah Agar anak didik memahami ajaran Islam secara elemantri ( sederhana ) dan bersifat menyeluruh. Sehingga dapat dijadikan sebagai pedoman dalam amal perbuatan serta membentuk manusia yang bertaqwa kepada Allah Swt., berakhlak dan terpanggil untuk melaksanakan amalan menurut tuntunan ajaran agama Islam.

Dari esensi tujuan pendidikan Islam sebagaimana terkutip di atas, maka penulis memberikan gambaran tentang tujuan pendidikan Islam sebagai berikut:

1. Agar anak memahami ajaran islam

2. Bertaqwa kepada Allah Swt.

3. Berbuat balik dalam kehidupan

4. Memahami dasar-dasar pendidikan islam

Allah Swt dalam Al-Qur'an As-Shaad: 29

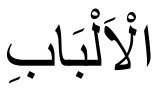

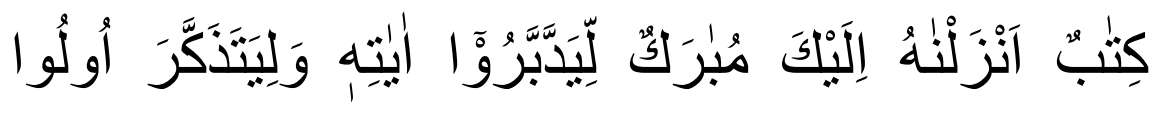

Terjemahannya :

"Ini adalah suatu kitab yang kami turunkan kepadamu dengan penuh dengan berkah supaya mereka memperhatikan ayat-ayat-Nya dan supaya mendapat pelajaran orang-orang yang mempunyai pikiran".

\section{Pendidikan Seks Dalam Islam Dan Tujuannya}

Berbicara masalah seksualitas, ada anggapan sementara dari sebagian masyarakat, bahwa masalah tersebut merupakan masalah yang tabu, kotor, menjijikan dan tak patut diperbincangkan apalagi bila masalah tersebut dikaitkan dengan masalah keagamaan.

Timbulnya persepsi semacam ini, disebabkan merembesnya paham-paham ajaran Gereja Masehi pada abad pertengahan di Eropa ke dalam benak manusia, adanya sistem kepasturan salah satunya yang tidak selaras dengan firah manusia. Dorongan seksual yang muncul pada diri manusia memerlukan pengaturan yang wajar dan sesuai dengan nilai moral. Begitu pula sebaliknya, dorongan seksual yang tidak disalurkan wajar dan sesuai dengan kaidah-kaidah moral hanya akan menimbulkan pengaruh yang negatif.

Berdeda dengan islam, masalah seksual dipandang sebagai sesuatu yang luhur dan suci. Islam menolak secara keras terhadap sistem kepasturan yang mencoba membunuh naluri seksual. Islam memandang bahwa dorongan seksual bersifat instinktif. Perkembangan manusia secara moral mesti memunculkan instinktif kearah yang positif, bukan mengekangnya secara terus-menerus, atau membiarkannya bebas lepas tanpa kendali. Seksual dalam islam adalah pengendalian dan penguasan terhadap dorongan seksual, atau menyalurkannya melalui cara yang sah, yakni melalui pernikahan.

Islam telah memberikan pedoman yang bersifat praktis, meskipun manusia diberi keleluasan untuk menyalurkan hasrat seksualnya, namun bukan berarti melaksanakan kebebasan seksual, sehingga didalam Islam terdapat aturan-aturan yang berkenaan dengan masalah seksual ini. Banyak petunjuk yang diberikan Al-qur'an, dan banyak pula contohcontoh perbuatan yang dilakukan Rasulullah Saw sebagai dasar pendidikan seksual, salah satu contoh ajaran Islam yang berkenaan dengan masalah seksual, yaitu larangan hidup membujang, 
menjaga pandangan mata terhadap lawan jenis yang bukan mahramnya, adab bersetubuh dan lain sebagainya.

Pendidikan seksual didalam Islam, merupakan pendidikan aqidah, akhlak, dan ibadah. Pendidikan seksual tidak bisa lepas dari ketiga unsur di atas. Keterlepasan pendidikan seksual dengan ketiga unsur unsur ini akan menyebabkan ketidak jelasan arah dari pendidikan seksual tersebut. Bahkan akan dapat menimbulkan kesesatan dan penyimpangan dari tujuan asal, sebab pendidikan seksual yang lepas dari aqidah akhlak dan ibadah hanyalah akan berdasarkan hawa nafsu semata (Syafruddin,1992). Pendidikan seks terdiri dari dua kata, yaitu pendidikan dan seks, pendidikan yaitu usaha dan kegiatan pembinaan pribadi (Drajat, 1996). Sedangkan seks dalam Kamus Besar Bahasa Indonesia adalah berkenaan dengan jenis kelamin; berkenaan dengan persetubuhan ( laki-laki dan perempuan). Pendidikan seks adalah penerangan yang bertujuan untuk membimbing serta mengasuh perihal pergaulan antar kelamin umumnya dan kehidupan seksual khususnya agar mereka dapat melakukan sebagaimana mestinya mendapatkan kebahagiaan manusia (Miqdad, 1997).

Pendidikan seksual yaitu, memberikan pelajaran dan pengertian kepada anak-anak baik laki-laki maupun perempuan sejak ia mulai memasuki usia baliq, serta berterus terang kepadanya tentang masalah-masalah yang berhubungan dengan seks, naluri dan perkawinan (Ath-Thawil, 2000). Berdasarkan beberapa definisi yang ada maka dapat disimpulkan bahwa yang dimaksud dengan pendidikan seks adalah suatu usaha untuk membimbing dan membina individu agar mengerti dalam menempatkan fungsi seks sehingga dapat menciptakan ketenagan dan kesejahteraan bagi keturunannya di masa yang akan datang.

Tujuan Pendidikan seks sesuai dengan kesempatan internasional, dalam International conference of Sex Education and Family Plaining tahun 1962 menyatakan bahwa:

"Tujuan pendidikan seks adalah untuk menghasilkan manusia-manusia dewasa yang dapat menjalankan kehidupan yang bahagia karena dapat menyesuaikan diri dengan masyarakat dilingkungannya serta bertanggung jawab terhadap dirinya dan terhadap orang lain"

Tujuan pendidikan seks menurut syariat Islam adalah "melangsungkan keturunan karena akan tercapai kehidupan seks yang dijalani dengan tuntutan agama akan menumbuhkan suasana yang harmonis, lahirnya generasi-generasi yang bertanggung jawab dan berbudi luhur serta akan mendorong semangat hidup dalam suasana cinta kasih sayang" (Shahli, 1994).

Tujuan pendidikan seks adalah memberikan pengarahan menuju perilaku seks yang benar dan menjauhkan seseorang dari seks bebas yang akan mengakibatkan hal-hal yang merugikan seperti kehamilan pra nikah, menyebabkan penyakit menular seksual seperti AIDS, Spilis, GO dll ( Yusuf, 2003).

"Tujuan pendidikan seks dalam syari'at Islam adalah untuk mencapai hidup bahagia didalam membentuk rumah tangga yang akan memberikan keluarga sakinah ( ketenangan) serta keturunan muslim yang taat kepada Allah dan selalu mendo'akan orang tuanya (Akbar, 1983).

Berdasarkan definisi yang ada, maka dapat disimpulkan bahwa tujuan diberikannya pendidikan seks adalah tidak lain untuk beribadah kepada Allah Swt, karena pendidikan seksual termasuk bagian dari pendidikan akhlak yang bertujuan untuk membentuk perilaku seksual yang sehat dan diliputi oleh iman kepada Allah Swt, karena pendidikan keimanan itulah sebenarnya menjadi pondasi diberikannya pendidikan seksual pada anak, hendaknya mampu mengarahkan diri anak untuk lebih dekat dan lebih mencintai Allah Swt, sehingga anak diharapkan dapat tumbuh dengan kepribadian muslim yang bertanggung jawab dan bertakwa kepada Allah Swt dan dapat menjalani kehidupan dengan selamat dan habagia.

\section{Pendidikan Seks Dalam Rumah Tangga}

Seksualitas merupakan pokok bahasan yang menyentuh begitu banyak aspek kehidupan manusia, seks tidak hanya sebatas tentang hubungan kelamin saja, tetapi juga mencakup antara lain proses kejadian manusia sejak dari pembuahan hingga proses kehamilan dan persalinan. Perkembangan fisik, psikis laki-laki dan perempuan, perilaku kelamin, kesehatan seksual, 
perilaku menyimpang, kejahatan seks, perlindungan hukum, penyakit menular seksual serta penanaman keimanan dan pendidikan akhlak.

Dalam Islam, sejak kecil manusia sudah diajarkan dan dilatih untuk terbiasa dengan identitas gendernya. Sejak manusia lahir, bayi akan diberikan pakaian dan aksesoris yang sesuai dengan identitas gendernya. Sesungguhnya hal ini sudah mencakup pendidikan seks bagi anak. Sesuai dengan usia perkembangannya, anak akan diberikan pemahaman tentang gender dan seksualitas dengan lebih mendalam. Hal ini pertama kali tentunya akan didapatkan dari lingkungan keluarga nya.Hanya saja banyak masyarakat masih tabu dalam mengajarkan masalah seksualitas kepada anak. Namun hal ini karena perspektif masyarakat yang masih menilai pendidikan seks yang berkonotasi tabu. Selain itu, banyak masyarakat yang tidak memberikan pemahaman kepada anak tentang fenomena bali>gh, $\mathrm{h}$ \}a>'id\}, dan lain-lain sebagaimana yang telah dijelaskan dalam kajian-kajian keislaman dan sesuai dengan penjelasan keislaman. Pemahaman tersebut perlu diberikan kepada anak paling tidak segera setelah ia mengalami fenomena tersebut, baik pengalaman pribadi, pengetahuan dari membaca, ataupun informasi dari teman dan sumber lain.

Keluarga merupakan mikrokosmos tempat manusia baru diciptakan dan merupakan sumber yang banyak memberikan dasar-dasar ajaran bagi seseorang dan merupakan faktor yang penting dalam pembinaan mental, sebelum seorang anak berinteraksi dengan lingkungan masyarakat terlebih dahulu menerima pengalaman-pengalaman dari keluarga di rumah, terutama ibu dan kemudian ayah dan kerabat-kerabatnya. Agar interaksi dengan anggota masyarakat berjalan dengan mulus dan tidak banyak mengalami rintangan maka diperlukan adanya landasan moral yang kuat untuk mendasari pembinaan keluarga tersebut (Ramayulis, 1998).

Sebagai sarana pendidikan, rumah tangga adalah lembaga pendidikan pertama yang dimasuki anak. Orang tua sebagai pendidik berfungsi sebagai guru, tetapi tugas orang tua menjadi pendidik merupakan tugas secara kodrati manusia sebagai orang tua dalam membimbing amanah Allah. Sementara keberadaan anak dalam rumah tangga dalam kaitannya dengan pendidikan kedudukannya adalah anak didik.

Orang tua memiliki potensi yang sangat besar dalam membentuk karakter anak. Dari didikan orang tualah akan membentuk kepribadian anak yang shaleh dan bertaqwa bahkan dari orang tualah juga dapat membentuk anak yang berkarakter yang tidak bermoral. Hal ini sebagaimana sabda Rasulullah Saw:

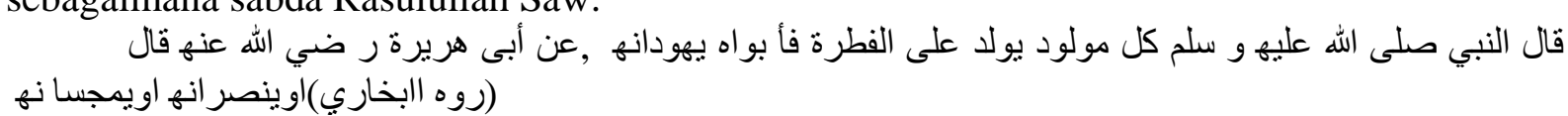

Terjemahannya :

"Dari Abu Hurairah r.a berkata Rasulullah Shallallahu 'alaihi wasallam setiap anak lahir itu dalam keadaan fitrah, orang tuanya lah yang menjadikannya yahudi, nasrani atau majusi". (H.R. Bukhari).

Hadist ini menunjukkan bahwa peranan orang tua sangat stategis dalam membentuk kepribadian anak, orang tua memegang peranan dalam menjalankan pendidikan anak untuk menentukan perkembangan anak selanjutnya.

Peranan pendidikan akhlak secara dini dapat dimulai dari lingkungan rumah tangga, dan selanjutnya dikembangkan dalam setiap tahapan pendidikan yang diberikan pada anak didik. Namun penanaman akhlak haruslah ditanamkan sejak dini. Ketika anak berada dalam rumah tangga akan banyak menentukan perkembangan kepribadian atau akhlak anak dalam tahaptahap perkembangan selanjutnya.

Pendidikan memiliki peran yang segnifikan bagi pertumbuhan dan perkembangan seks anak. Karena pendidikan dapat memberikan arah bagi perkembangan jiwa sang anak. Pendidikan tersebut harus dititik beratkan pada materi-materi pendidikan seks sehingga anak dengan mudah dapat memahami pentingnya seks, bahaya seks bebas dalam kehidupannya.

Anak 7-10 tahun materinya yaitu menghindarkan matanya dari hal-hal yang belum pantas untuk dilihat seperti media sosial yang berbau pornografi, tayangan-tayangan yang erotis dan lain-lain. 10-14 tahun menjauhkan anak dari rangsangan seksual. Pendidikan seks yang diajarkan lebih ditekankan kepada pengaruh seks bebes. Pada masa usia remaja mereka sudah 
sanggup menangkap secara utuh tentang seks itu sendiri, sehingga materi tersebut lebih ditekankan pada pengertian seks, pengaruhnya yaitu tentang penyimpangan seksual, seperti sodomi, onani, perzinahan dan lain-lain. Adapun dampak buruk dari pengimpangan seksual itu sendiri seperti timbulnya penyakit AIDS, Raja singa, Spilis, dan lain-lain.

Selain itu orang tua juga hendaknya menimbulkan sifat rasa takut anak kepada Allah Swt, karena memberikan contoh-contoh agung dari kesucian diri melalui kisah-kisah orang alim terdahulu, seperti kisah Nabi Yusuf, kisah seorang istri di masa Umar Bin Khatab ra, kisah seorang pemuda dengan seorang gadis maupun kisah-kisah lain yang dapat memberikan manfaat khususnya bagi pertumbuhan seks pada diri anak. Orang tua juga hendaknya memperingatkan anak terhadap orang-orang yang melanggar larangan Tuhan mengenai seks, baik hukuman didunia maupun di akhirat. Serta balasan pahala bagi orang yang menjaga kesucian diri. Dari materi tersebut diharapkan dapat memberikan masukan bagi anak didik tentang pengaruh yang ditimbulkan oleh seks bebas dan betapa indahnya seks secara sehat yang sesuai dengan tuntunan Islam, perlunya materi tersebut di ajarkan bagi anak karena beredarnya produk vidio porno yang telah membawa efek negatif bagi perkembangan jiwa anak saat sekarang. Tontonan yang paling menonjol dapat dilihat ketika pornografi dapat dilakukan secara bebas saat sekarang. Gejala ini menurut Boyke mengakibatkan munculnya beberapa faktor gejala seksual yang melanda remaja usia dini diantaranya :

1. Anak yang memasuki usia pubertas tidak mampu menahan gejala seks yang ia lihat melalui hasil tontonannya, akibat gejala itu akan membawa diri melakukan pergaulan bebas yang mengakibatkan terjadinya kehamilan.

2. Perkembangan usia dari masa kanak-kanak hingga remaja merupakan rentang usia dimana seorang remaja masih membutuhkan arahan, jika anak usia dini dihadapkan dengan tontonan yang bersifat glamor akan memungkinkan terjadinya pengaruh pergaulan yang bersifat glamor.

3. Kecenderungan anak dalam meniru apa yang ditontonnya sangat tinggi, sehingga apa yang ia baca atau tonton merupakan referensi yang akan dilaksanakan dalam pergaulannya.

4. Masa pertumbuhan merupakan masa transisi dimana setiap orang akan merasa bangga kalau apa yang ia laksanakan itu merupakan hal baru sehingga pada masa ini seorang anak usia dini merasa bangga jika ia mampu berkencan dengan lawan jenisnya.I

Berdasarkan pernyataan yang ada, merupakan bentuk dari kebebasan seks yang diakibatkan oleh informasi dan teknologi yang melanda anak remaja pada saat ini. Gejala ini lebih diperparah dengan munculnya kebebasan dari komersialisasi produk-produk yang membahayakan seperti rumah bordir, hotel-hotel mewah, obat-obatan seks dan sebagainya yang akan membawa dampak negatif bagi pertumbuhan dan perkembangan anak.

Pendidikan seksual adalah upaya pengajaran, penyadaran dan penerangan tentang masalah-masalah seksual yang diberikan kepada anak sejak ia mengerti masalah-masalah yang berkenaan dengan seks, naluri dan perkawinan. Sehingga kelak anak tumbuh menjadi dewasa serta dapat memahami urusan-urusan kehidupan. Maka ia akan mengetahui masalah-masalah tentang apa yang diharamkan dan dihalalkan. Bahkan mampu menerapkan tentang tingka laku Islami sebagai akhlak, kebiasaan dan tidak dapat mengikuti syahwat dan cara-cara hedonisme ( Ulwan, 1993)

\section{Bentuk Pendidikan Seks Pada Anak Dalam Rumah Tangga}

Mengingat keluarga merupakan lembaga yang paling utama dalam pengembangan pendidikan seks pada anak,maka orang tua harus memahami perkembangan psikologis anak sesuai dengan usianya,hali ini bertujuan agar orang tua tidak salah dan tepat dalam memberikan dan menerapkan pendidikan seks pada anak.

Sehultz (2005) mengemukakan bagaimana perkembangan seks pada anak dan kaitannya dengan usianya,yaitu Pada usia 0-3 tahun, pendidikan seks diawali dengan pemberian identitas fisik pada anak. Seperti berpakaian, aksesoris, dan sebagainya. Mengenai hal ini Ibnu Sina menjelaskan bahwa anak laki-laki tidak boleh diberikan pakaian yang berwarnawarni, karena ini 
akan merusak karakternya. Begitupula pada anak perempuan agar dihindari memakai pakaian dan aksesoris yang gelap.

Pada usia 4-6 tahun, anak sudah mulai bisa berkomunikasi. Orang tua harus hati-hati dalam berkomunikasi pada anak. Usia 4-6 tahun adalah usia yang sangat kuat ingatannya. Bahkan Ibnu Sina menganjurkan anak untuk menghafal Qur'an pada usia 5-7 Tahun. Pada usia anak biasanya sudah mulai bergaul dengan temanteman sebayanya dalam rangka untuk bermain. Orang tua harus mengontrol bermain anak, harus diperhatikan teman laki-laki dan teman-teman perempuannya. Jika anak laki-laki bermain dengan kelompok anak perempuan, tentunya ini akan berdampak negatif pada pola perilaku anak.

Pada usia 7-10 tahun, anak harus dipisahkan dari ranjang, sebagaimana dijelaskan dalam hadits. Karena pada usia ini anak sangat ingin mengeksplor apa yang ada di sekitarnya. Maka keberadaan anak dari wilayah privasi suami-isteri harus dijauhkan. Apalagi jika sudah mendekat usia 10 tahun, usia di mana dalam proses menuju pubertas, mulai memahami gender dan lawan jenis. Bahkan saat ini tidak jarang anak usia 8-10 tahun sudah mulai ada ketertarikan terhadap lawan jenis. Anak pada usia ini harus diberikan batasan yang normal terhadap lawan jenis. Jangan terlalu banyak bergaul dengan lawan jenis, dikhawatirkan ketika sudah masuk masa pubertas (bali>gh) anak tidak terbiasa. Tidak pernah sama sekali bergaul dengan lawan jenis juga tidak baik, karena bergaul dengan lawan jenis juga berguna agar anak belajar untuk memahami perbedaan gender. Secara kognitif, anak usia 7-10 harus diberikan doktrin mengenai hubungan antara lawan jenis, pembelajaran fiqh pada usia ini cukup membantu. Karena pada usia ini, perkembangan kognitif pada anak sudah mulai berpikir secara objektif dan logis.

Tidak hanya pembelajaran fiqh, pembelajaran akhlaq dan etika juga sangat penting. Ini untuk melembutkan hatinya, menyiapkan ru>hiyyah-nya agar siap menghadapi ujian syahwat yang begitu besar di usia perkembangan selanjutnya. Usia 11-14 tahun, adalah masa pubertas. Terjadi perubahan besar dari berbagai dimensi. Menurut Psikoanalisa, pada usia pubertas, kelamin adalah zona kenikmatan. namun karena harus menyesuaikan diri dengan norma, dorongan seksual tertekan, dorongan tersublimasi menjadi keinginan untuk menjalin hubungan dengan lawan jenis. 28

Berdasarkan pendapat diatas maka pendidikan seks dalam islam dibagi menjadi 4 fase,yaitu :

a. Fese pertama yaitu anak usia 7-10 tahun, menurut ajaran Islam bahwa anak usia ini harus di ajarkan tentang etika meminta izin apabila masuk kekamar orang tua serta etika untuk memandang muhrim.

Hal ini sebagaimna firman Allah Swt dalam Q.S. An-Nur: 58

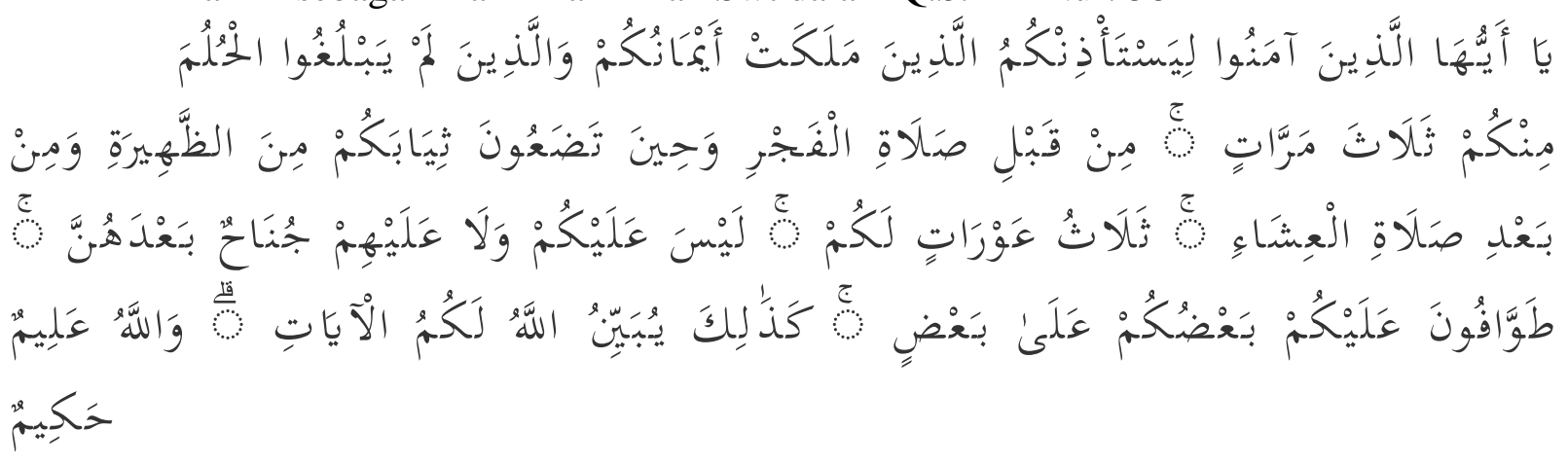

Terjemahannya:

"Hai orang-orang yang beriman, hendaklah budak-budak (lelaki dan wanita) yang kamu miliki, dan orang-orang yang belum balig di antara kamu, meminta izin kepada kamu tiga kali (dalam satu hari) yaitu: sebelum sembahyang subuh, ketika kamu menanggalkan pakaian (luar)mu di tengah hari dan sesudah sembahyang Isya'. (Itulah) tiga aurat bagi kamu. Tidak ada dosa atasmu dan tidak (pula) atas mereka selain dari (tiga waktu) itu. Mereka melayani kamu, sebahagian kamu (ada keperluan) kepada sebahagian (yang lain). Demikianlah Allah menjelaskan ayat-ayat bagi kamu. Dan Allah Maha Mengetahui lagi Maha Bijaksana." 
Menurut ayat tersebut bahwa Islam memberikan tuntunan tentang tata tertib bergaul didalam kehidupan rumah tangga, tiga waktu yang tidak diperbolehkan bagi anak-anak atau pelayan untuk memasuki ruang yang ditempati oleh, orang dewasa, kecuali meminta izin terlebih dahulu baik dengan cara salam atau dengan mengetuk pintu, tiga waktu itu, yaitu waktu sebelum sholat subuh, waktu siang hari ( tengah Hari) waktu setelah sholat Isyah.

Peran orang tua disini adalah agar selalu mengingatkan anak-anaknya agar selalu meminta izin terlebih dahulu sebelum memasuki kamar orang tuanya pada tiga waktu yang telah ditentukan dalam jaran agama Islam.

Aturan tersebut ditetapkan mengingat diantara tiga waktu tersebut merupakan aurat, waktu dimana badan atau aurat banyak terbuka, bila pendidikan semacam ini ditanamkan pada seorang anak niscaya ia akan menjadi seorang anak yang penuh dengan sikap sopan santun, anak akan memiliki prinsip etika yang luhur (Syafruddin, 1992)

Secara psikologis kondisi kejiwaan anak pada usia antara 7-10 tahun masih di dominasi oleh sifat imitasi ( suka meniru) tanpa pertimbangan yang matang sehingga apabila besar masuk kekamar orang tua tanpa izin terlebih dahulu, maka dikhawatirkan akan menyaksikan sesuatu adegan yang akan menjadi bahan tiruannya.

Ulwan (1993) menyatakan bahwa: "betapa besarnya suatu bahaya jika seseorang secara tiba-tiba anak memasuki kamar tidur dan melihat orang tuanya sedang melakukan hubungan seksual lalu kelaur dan menceritakannya apa yang telah dilihatnya kepada teman-temannya."

Kaidah minta izin yang di bangun Islam dan para pakar pendidikan seks modern dengan target pada suatu tujuan yang asasi, yaitu menjauhkan anak dari melihat pemandangan aktivitas hubungan seksual diantara suami istri sehingga anak nantinya terpengaruh dengan meniru rahasia sesuatu karena ketidaktahuannya, jika seorang anak tidak dilatih kaidah ini, maka akan menimbulkan kerusakan pada diri anak-anak.

Pada usia ini pula anak hendaknya orang tua mengajarkan kepada anak tentang adab memandang yaitu dengan membiasakan dan menerapkan pandangan kepada hal-hal yang halal, hal ini dimaksudkan agar anak dapat mengetahui masalah-masalah yang dihalalkan dan diharamkan, sehingga ketika anak sudah mendekati masa baliq dan telah mencapai masa taklifnya, ia telah dibekali dengan akhlak yang lurus dan mantap.

Hal ini dapat dimulai dari orang tua, yang selalu menjaga auratnya dihadapan anaknya, dan tidak serampangan dalam memperlihatkan auratnya didepan anak-anaknya, misalnya pada saat ayah dan ibu sedang berganti pakaian, hendaknya janganlah pada saat anak itu ada dekat dengannya, karena hal sekecil itu pun dapat mempengaruhi watak anak. Jika anak terbiasa melihat hal-hal seperti ini, maka ini dapat memberikan keberanian pada diri anak untuk melihat hal-hal semacam ini di tempat lain.

b. Fase kedua, yaitu pada usia 10-14 tahun, fase ini anak memasuki masa remaja, yaitu masa yang berbahaya kerena kehidupan seksual sudah mulai matang.

Masa remaja ini merupakan suatu masa yang sangat menarik perhatian para ahli, banyak ahli yang berpendapat bahwa hakikat dari masa ini tidaklah mengherankan bahwa penyelidikan yang mengenai anak-anak masa remaja itu dilakukan dalam kehidupan seksual, terutama para dokter (Drajat,1997).

Masa remaja adalah masa kematangan kehidupan seksual. Oleh sebab itu diperlukan kehati-hatian dan kewaspadaan orang tua apabila diambang pintu keremajaan untuk menjauhi hal-hal yang dapat menimbulkan rangsangan seksual.

Menurut ajaran Islam, langka awal menghindarkan anak dari rangsangan seksual adalah memisahkan temapat tidur saudaranya, agar anak tersebut dapat membedkan serta tidak terpengaruh pada kehidupan seks bebas yang melanda dirinya ketika usia pubertas.

Rasulullah Saw bersabda :

"Perintahkan anak-anak kalian untuk melakukan salat saat usia mereka tujuh tahun, dan pukulah mereka (jika meninggalkannya) saat usia sepuluh tahun. Dan pisahkan tempat tidur mereka. 
Berdasarkan pakar ilmu jiwa kebangsaan Amerika Serikat sejalan dengan pandangan syari'at tentang pentingnya pemisahan tempat tidur. Dalam kehidupan anak di Amerika berkata:

"Secara mutlak tidak wajib anak-anak tidur bersama dalam satu tempat tidur mereka, sebab anak yang tidur bersama dalam satu tempat tidur, walaupun bentuknya ditata sedemikian rupa, tetap akan bersentuhan antara satu dengan yang lainnya dan akan menyeret pada permainan seks".

Untuk itu hendaklah orang tua bertindak tepat dalam memisahkan tempat tidur anak, baik antara orang tua dangan anak maupun antara anak dengan saudaranya.Hal ini dilakukan sebagai sarana pencengahan untuk menjaukan anak baik yang telah menganjak usia tamyiz atau bealum dari kegiatan seksual yang dilakukan oleh pasangan suami istri, atau hubungan seksual yang mungkin saja terjadi antara sesama saudara yang berada dalam satu tempat tidur yang sama.

c. Fase ketiga, yaitu fase pada usia 14-16 tahun, masa ini adalah masa adolesen. Pada masa ini kematangan seksual mulai sempurna, oleh karena itu anak cenderung merasa terdorong untuk melakukan hubungan seksual.

Kehidupan masa remaja atau masa pubertas menunjukkan perkembangan jiwa seorang anak, pada masa ini keinginan seseorang untuk melakukan segala seksual yang dapat membuat ia merasa senang mampu mengiring ia melakukan seks secara bebas (Dian , 1999). Pada usia seperti ini seorang anak telah mengerti tentang perbedaan antara laki-laki dan perempuan, maka hendaknya orang tua memberikan pengertian yang lebih dalam sebagaimana pergaulan adab memandang wanita atau pria yang muhrim maupun yang bukan muhrim. Pada fase ini pula anak didik untuk tidak boleh melakukan iktilat, yakni bercampur-baurnya antara laki-laki dan wanita yang bukan mahram, karena sebagai perantara kepada perbutan zina yang diharamkan Islam.

Kepada orang tua dan pendidik, hendaknya membiasakan kepada anaknya untuk selalu bergaul deangan sesama jenisnya. Banyak efek psikologis yang bisa ditimbulkan akibat pergaulan yang bercampur baur antara laki-laki dan wanita yang bukan mahramnya. Apabila disaat anak tengah mengalami pertumbuhan kepribadian, dimana kemampuan untuk melakukan imitasi terhadap suatu sikap atau perilaku sangat besar. Selain itu anak juga harus dididik agar tidak melakukan khalwat, yaitu bila seseorang laki-laki dan perempuan yang bukan mahramnya berada disuatu tempat yang hanya berdua saja, perbuatan seperti itu diharamkan dalam Islam karena dapat membuka pintu perzinahan.

d. fase keempat, yaitu usia ke -20 tahun, pada masa ini anak sudah matang untuk menikah, gejala seks yang paling mendominasi pada saat ini adalah keinginan untuk melakukan hubungan kelamin dengan lawan jenis.

Pada masa ini anak hendaknya diberi pelajaran tentang adab melakukan ist'fat ( bersuci, jika ia memang belum mampu menikah) (Ulwan, 1993) Pada fase ini jika anak telah mampu menikah, maka anak dianjurkan untuk segera menikah, hal ini dilakukan untuk menghindarkan anak dari perbuatan zina.

Pada fase ini juga, orang tua sudah dapat mengajarkan kepada anaknya tentang perkawinan, yang merupakan jalan kokoh para Nabi, kebebasan dalam menikmani seks halal, hak dan kewajiban suami istri, serta aturan-aturan dalam menjaga kesucian dan kehormatan diri dalam perkawinan. Hal ini tidak lain bertujuan untuk menajdikan anak paham tentang seks dalam ajaran agama Islam. Sehingga dapat berjalan sesuai dengan tuntunan Islam, dengan lahirnya rumah tangga yang bahagia, sakinah, mawaddah dan rahmah.

Cara islami lain dari pendidikan seksual yang harus diajarkan orang tua terhadap anaknya adalah sebagaimana yang telah dicontohkan Rasulullah saw mengenai hal menjaga kesehatan seksual, ini merupakan sunnnah dari pada Rasulullah saw.

1. Mencukur rambut kemaluan

2. Mencabut bulu ketiak

3. Khitan 
4. Istinja

5. Mandi

\section{KESIMPULAN}

Dari beberapa pembahasan yang penulis kemukakan diatas, maka dapatlah disimpulkan sebagai berikut :

1. Pendidikan seks sejak dini sangatlah dibutuhkan, karena pendidikan seks mampu melakukan pembinaan terhadap perilaku seks anak, hal ini bertujuan untuk mengantisipasi anak menjadi korban kejahatan seksual tetapi juga mencengah anak menjadi pelaku dari kejahatan tersebut yang disebabkan adanya kelainan seksual.

2. Pendidikan seks diberikan melalui materi pelajaran pendidikan agama, moral, kesehatan dan kejiwaan, yang dilakukan dalam rumha tangga oleh orang tua berdasarkan Al-Qur'an dan hadist Rasulullah saw, serta tauladan yang baik dari orang tua itu sendiri.

3. Dengan memberikan pendidikan seks pada anak sejak usia dini maka kelak anak akan tumbuh dengan budi pekerti yang sesuai dengan ajaran islam sehingga anak akan menjalani kehidupan yang tentram dan bahagia..

\section{DAFTAR PUSTAKA}

Arifin H.M. (1994). Pengantar Filsafat Pendidikan Islam. Cet. IV Jakarta : Bumi Aksara.

Akbar Ali. (1983). Seksualitas Ditinjau Dari Hukum Islam. Jakarta : Ghalia Indonesia.

Ath-Thawill Utsman. (2000). Ajaran Islam Tentang Fenomena Seksual. Cet ii ; Jakarta : PT Raya Grafindo Persada.

Departemen Pendidikan dan Kebudayaan. (1995). Kamus Besar Bahasa Indonesia.cetakan ketujuh Jakarta : Balai Pustaka.

Drajat Zakiah. (1996). Ilmu Pendidikan. Jakarta : Bumi Aksara

Nugroho Dian Boyke. (1999). Remaja Dalam Kehidupan Global. Makalah Seminar Nasional. Jakarta: h.2

Indrawati Dewi. 2005. Pendidikan Seks Dalam Perspektif Ali Akbar. 2005:1. Tesis Dari Pascasarjana Universitas Islam Negeri Syarif Hidayatullah. Jakarta

Langgulung Hasan. (1985). Manusia Dan Pendidikan. Cet.1 Jakarta: Pustaka Al Husna.

Marimba Ahmad D. (1994). Filsafat Pendidikan Islam. Cet.IV Jakarta: Bumi Aksara

Miles, B., \& Huberman A. Michael (2003). Pedoman Penulisan Skripsi Dan Makalah Sekolah Tinggi Agama Negeri. 2003:6-8

Miqdad Abu Azhar Akhmad. (1997). Pendidikan Seks Terhadap Remaja Menurut Hukum Islam. Yogyakarta: Mitra Pustaka.

Munawir Ahmad Warson. (1997). Kamus Besar Arab Indonesia Al- Munawir. Cet XIV Surabaya: Pustaka Progresif.

Muslim Imam. (1955). Shahih Muslim. Juz IV Kairo: Isa Al-Baahi Al - Halabi was Syirkah. Ramayulis. (1998). Ilmu Pendidikan Islam. Cet III jakarta: Kalam Mulia.

Redha Rasyid Muhammad. (1935). Al-Tarbiyah $W$ Ta'lim Al-Islamiyah. Al-Manar: XXXIV,No.7, $1342 \mathrm{H}$.

Rusydi Ahmad. (2012). Pendidikan Seks Dalam Perspektif Psikologis Islam. https://www.researchgate.net/profile/Ahmad-

Rusdi/publication/317063673_Pendidikan_Seks_dalam_Perspektif_Psikologi_Islam/ links/5923e7b00f7e9b99794877b6/Pendidikan-Seks-dalam-Perspektif-PsikologiIslam.pdf

Schultz \& Schultz. (2005). Theories of personality. Eight Edition Belmont-USA: Thomson Wadsworth.

Shahli Mahfudh. (1994). Etika Seksual. Cet.IV Pekalongan: CV. Bahagia.

Syafruddin Ayip. (1992). Islam Dan Pendidikan Seks Anak. Cet. Solo. CV. Pustaka mantiq. 
Ulwan Nashih Abdullah. (1993). Pedoman Pendidikan Anak dalam Islam. Cet. III; Jakarta: AsSyifa.

Yusuf Syaiful. Makalah Pendidikan Seks Dalam Islam. 